\title{
EDITORIAL
}

\section{CUIDAR A LOS QUE SON DE CULTURAS DIFERENTES REQUIERE EL CONOCIMIENTO Y LAS APTITUDES DE LA ENFERMERÍA TRANSCULTURAL}

\author{
MADELEINe Leininger
}

$P h D, L H D, C T N, R N, F A A N, L L$.

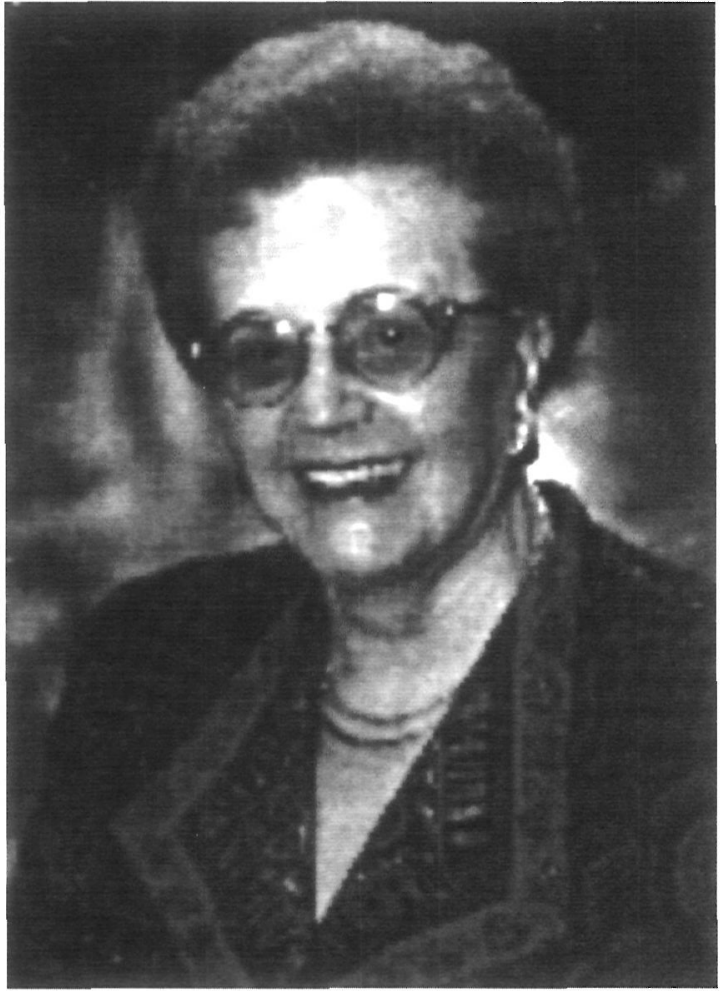

T a Dra Leininger es profesora emérita en la Universidad Estatal de Wayne (Detroit, Michigan) y profesora adjunta de la Escuela de Enfermería de la Universidad del Centro Médico de Nebraska. Es la fundadora del campo de la enfermería transcultural, además de una líder en teoría e investigación. A la vez que nuestro mundo se hace más diverso y complejo, una se da cuenta que necesita conocer y entender a las personas que hablan y se comportan de otro modo. Las enfermeras tenemos un rol único para conocer y entender a estas personas y a sus familias cuando son cuidadas. De todas maneras, necesitamos estar preparadas para ser competentes en el cuidado de personas de diferentes creencias y maneras de vivir. Es un imperativo de orden mundial para las enfermeras si queremos realizar nuestra función con efectividad y conocimiento en el siglo XXI. Con anticipación a esta crítica necesidad, creé en los primeros años cincuenta el campo de estudio y trabajo de la enfermería transcultural (ETC), y ha ido creciendo por todo el mundo como un imperativo para las enfermeras profesionales (Leininger 1970, 1978, 1995). La idea de la enfermería transcultural, como área especial de estudio, era nueva para muchas enfermeras, por lo que la progresión y comprensión fue lenta hasta últimos de los ochenta. La falta de programas de educación era evidente hasta hace pocas décadas. Hoy la enfermería transcultural está bien asentada, y las enfermeras pueden aprender y utilizar los conceptos, principios y el conocimiento basado en la investigación de la ETC, y así proporcionar cuidados culturalmente aceptables para inmigrantes, refugiados y personas de otras culturas y subculturas. La ETC es considerada hoy como una de las inflexiones más significativas de la enfermería, y aun será más importante y necesaria para toda la enfermería del siglo XXI. Debido al enfoque holista de los seres humanos de la ETC, hace diferentes los cuidados de salud de cada persona, en su recuperación, en su bienestar, o en su proceso de muerte (Leininger 1978, 1995).

_ ¿Qué es la Enfermería Transcultural?

Para saberlo es importante entender el significado y el objetivo de la ETC. Como fundadora de esta disciplina, he definido la ETC como el área formal de estudio y trabajo centrado el cuidado basado en la cultura, creencias de salud o enfermedad, valores y prácticas de las personas, para ayudarlas a mantener o recuperar su salud, hacer fren- 
te a sus discapacidades o a su muerte (Leininger 1978, 1995). Los conceptos de cultura y cuidado están íntimamente relacionados al establecer la filosofía, naturaleza y esencia de la ETC como un nuevo cuerpo de conocimientos y acción en la enfermería. El concepto de cultura viene de la antropología, y el de cuidado de la enfermería para ser unidos en un marco mayor. Esencialmente, la cultura se refiere a las creencias, valores, símbolos, estilos de vida de una cultura particular y que son aprendidos, practicados y generalmente transmitidos de generación a generación cómo normas de comportamiento en la vida; mientras que el concepto de cuidado viene de la enfermería. He definido cuidado como la esencia y acto diferenciador de la enfermería que permite a las personas mantener o restablecer su salud o bienestar o afrontar su enfermedad, su discapacidad o su muerte (Leininger 1970, 1981, 1988,1991). Al sintetizar cultura y cuidado, se creo el campo de la enfermería transcultural. El conocimiento basado en la investigación ha sido desarrollado mediante prácticas creativas que han permitido varios modos de conocer, entender y cuidar a personas de diferentes o similar cultura. La ETC se convierte en significativa cuando las enfermeras se centran simultáneamente en la cultura y en los cuidados de las personas, en su modo de vida, en su curación, o en ayudarles a hacer frente a su discapacidad o a su muerte. Proporcionando cuidados culturalmente apropiados y seguros hace la diferencia para que las personas mejoren, permanezcan enfermas o empeoren. Así la ETC se ha convertido en área de estudio y trabajo único y diferente durante las cuatro últimas décadas. Las creencias, valores y estilos de vida deseados de los seres humanos han sido incorporados a la enfermería y a los servicios de salud.

— ¿Por qué es la Enfermería Transcultural tan importante hoy en día?

La ETC es importante hoy dada la gran movilidad de las personas y los modernas tecnologías en comunicación y transporte. Los seres humanos se están moviendo y comunicando con personas con estilos de vida muy rápidos. De acuerdo con esto, se espera de las enfermeras que cuiden a los extranjero culturas de diferentes hoy más que en el pasado. Otras razones específicas y principios de acción se ofrecen a continuación. Primero, todos los seres humanos nacen, crecen y mueren y esperan ser cuidados según una perspectiva cultural. Segundo, el cuidado culturalmente apropiado se convierte en significativo para las personas que están enfermas o sanas y es potente generador de progresos curativos. Tercero, las enfermeras necesitan incorporar valores, creencias y modos de vida a sus cuidados, para que mejoren o que sean congruentes con el estilo de vida e intereses de las personas para beneficiarlas terapéuticamente. Cuarto, un cuidado profesional y culturalmente apropiado demuestra capacidad curativa para las personas y refuerza mi creencia que no puede haber curación sin cuidado. Quinto, la recuperación de la enfermedad, o de las discapacidades, o el afrontamiento de la muerte necesita que la enfermera comprenda la totalidad de la manera de ser de las personas y sus maneras de cuidar para ayudarles. Sexto, aunque el cuidado integral y los factores culturales son a menudo invisibles, o poco valorado por la sociedad, son con frecuencia factores críticos para ayudar a las personas. Séptimo, lo que más quieren las personas cuando van a un hospital, a una clínica o a cualquier agente de salud es un buen cuidado de enfermería, que demuestre conocimiento y sensibilidad a los que están siendo cuidados. Las enfermeras, como principales realizadoras de cuidados tienen una oportunidad especial para hacer enfermería transcultural. Octavo, cuando los valores culturales del cuidado son comprendidos y realizados por las enfermeras se evita la no cooperación de las personas y que se sientan incomprendidas o rechazadas. Así, la ETC es necesaria para que las enfermeras de hoy consigan el objetivo de promocionar el cuidado culturalmente apropiado. La ETC hace del cuidado algo con significado y proporciona muchas recompensas al cuidar a personas de culturas diferentes. El objetivo de la ETC es entonces, proporcionar cuidados culturalmente adecuados a personas de diferente o parecida cultura (Leininger 1978,1995). El concepto de cuidado culturalmente adecuado según la teoría de «Cuidado Cultural en la Diversidad y la Universalidad» es importante para conseguir este objetivo y descubrir nuevos conocimientos para la práctica enfermera. La teoría ayuda a guiar a las enfermeras en el descubrimiento de nuevos cono- 
cimientos, y a hacer afirmaciones, tomar decisiones y realizar acciones que son beneficiosas y significativas para las personas que cuidan (Leininger 1991). Lo más importante, la teoría ayuda a las enfermas a descubrir cuidados culturales específicos para personas de culturas diversas, como la hispana, la africana, la anglo-americana, la griega, la italiana, la portuguesa, y muchas otras que una enfermera puede encontrarse en cualquier día o noche. Y proporcionar un cuidado culturalmente adecuado necesita el uso de la investigación desarrollada con estrategias creativas que se adapten al modo de vivir de las diferentes culturas. Con la práctica de la ETC, las enfermeras encontrarán personas cooperativas y que se sienten respetadas y que sienten entendidos su herencia cultural y su modo de vida. Más y más personas esperan de las enfermeras que entiendan y respeten sus valores culturales y creencias y que les ayuden de una manera significativa y apropiada. Así, el propósito de la ETC es continuar descubriendo nuevas y beneficiosas formas de ayudar a las personas de diferentes culturas, siendo el objetivo de la ETC proporcionar cuidados culturalmente apropiados (Leininger 1991, 1995). Cuando estas proposiciones y objetivos se mantienen, entonces las personas que cuidemos no experimentarán situaciones negativas como la imposición cultural y otras situaciones poco favorecedoras que a continuación trataremos brevemente mediante ejemplos.

-Etnocentrismo e Imposición Cultura 1: Conceptos importantes que conciernen a las enfermeras.

Etnocentrismo e imposición cultural son conceptos de extremada importancia que las enfermeras deben entender. El etnocentrismo se refiere la creencia que los propios valores, creencias y maneras de conocer y hacer son las mejores, o superiores a otras (Leininger 1978,1995). Los problemas 1legan cuando estas creencias son muy fuertes y controlan de manera no deseable a otros que son culturalmente diferentes.

La imposición cultural se refiere a la tendencia de imponer los propios valores, creencias y prácticas etnocéntricas a otra persona o grupo, limitando su libertad y respeto al ser humano (Leininger 1995). La imposición cultural está íntimamente relacionada con el etnocentrismo, porque con frecuencia el etnocentrismo conduce a la imposición cultural. Ambos conceptos suelen llevar a choques, daños y conflictos culturales entre clientes y enfermeras. Unos cuantos ejemplos culturales ayudaran a reconocer la relevancia e importancia del etnocentrismo y la imposición cultural en situaciones de enfermería transcultural y ayudarán también a prevenirlas en situaciones de cuidado.

Situación 1: La señora José es una madre de 35 años de origen mexicano, que viene al hospital a realizar una revisión a su bebé de tres meses. Las enfermeras de pediatría se quedaron encantadas al ver ese «rollizo y sonriente bebé», así que empezaron a mirarle diciendo a su madre continuamente «iqué niño más guapo con esos ojos y ese pelo!». La madre se enfadó y apartó a las enfermeras. Enseguida salió del hospital pensando que las enfermeras estaban echando mal de ojo a su hijo. Las enfermeras se enfadaron por el comportamiento de la madre, pero aprendieron de una especialista en ETC que mirar fijamente y celebrar a los bebés mexicanos puede ser visto por sus madres como «estar echándoles mal de ojo». Se cree que este comportamiento puede enfermar al bebé o incluso traerle la muerte. La madre estaba muy pendiente del comportamiento de las enfermeras, y se llevó a su bebé para evitar el daño y la enfermedad. La enfermera transcultural enseñó a las otras enfermeras a acariciar a un niño y celebrar su belleza, a la vez que evitar dañarle. Este conocimiento sobre las creencias de los demás es prioritario para las enfermeras si quieren conocer y procurar sus cuidados. En esta situación, el modo etnocéntrico en que la enfermera profesional celebra la beldad de los niños, supone una verdadera amenaza para la madre y el bebé mexicanos.

Situación 2: Otro incidente común en la ETC está relacionado con el significado y expresión del dolor, y cómo manejar este dolor en personas de distintas culturas. Es bien conocido en la ETC que el dolor varía entre personas de diferente cultura, y que no pueden ser tratados de igual manera. La señora Senaro, filipina, católica, de 55 años es sometida a cirugía uterina. El médico prescribió «una dosis alta de medicación post-quirúrgica para aliviarle cualquier dolor». La señora Senaro oyó al médico decirle esto a la enfermera. Más tarde, la señora Senaro le dijo a la enfermera «por favor, no me dé mucha medicina». Después de la primera 
inyección, no volvió a pedir más medicación para el dolor, rechazando los ofrecimiento de la enfermera, ya que suponía que tendría dolor. Ésta cumplía con la petición de su cliente, pero no entendía el motivo por el cual no quería analgésicos. Más tarde, una especialista en ETC que trabajaba en el mismo hospital le explicó los motivos culturales de rechazo de la medicación. Le dijo que los motivos para rechazar la medicación eran el miedo a hacerse adicta a esa droga, un aceptado estoicismo, y el valor redentor que le daba al sufrimiento como católica romana Por estas importantes razones la señora Senaro no quería medicación para el dolor y rechazaba las ofertas de la enfermera. Ésta estuvo tentada de hacer una imposición cultural, pero aprendió que las diferentes respuestas culturales al dolor en una cultura o entre culturas diferentes deben ser respetadas.

Incidente 3: El cuidado a los testigos de Jehová es a menudo dificultoso para las enfermeras y el resto de profesionales, a1 manejar situaciones dónde está médicamente indicada una transfusión de sangre, que son vistas como necesarias desde el punto de vista profesional. Aun así, los testigos de Jehová tienen una creencia diferente sobre las transfusiones sanguíneas. Abie, una mujer de 27 años, testigo de Jehová, fue admitida en un hospital para una operación. En la admisión inmediatamente le dijo a la enfermera y al médico que bajo ninguna circunstancia quería recibir una transfusión de sangre ni antes, ni durante, ni después de la operación. Ni la enfermera ni el médico sabían cómo reaccionar ante aquella expectativa, ya que ambos querían cubrir su responsabilidad como profesionales y mantener sus etnocéntricas creencias profesionales. Para el médico el Juramento Hipocrático era muy importante, de igual modo que para la enfermera su código deontológico. Así, el problema moral y ético era evidente al estar prohibidas las transfusiones de sangre según las creencias religiosas de Abie. La enfermera y el médico aceptaron su petición, pero temían por su supervivencia. Aun así, Abie y su familia rogaron encarecidamente que no recibiera ninguna transfusión durante la operación. La recuperación fue buena y su familia se sintió aliviada al saber que nadie había impuesto a Abie ni sus creencias ni sus valores culturales. Abie también estaba aliviada al saber que no hubo ninguna transgresión de la Ley de Dios realizando alguna transfusión, lo que habría significado pasar la eternidad en la «nada». La enfermera y el médico practicaron la ETC y rechazaron las prácticas de imposición cultural.

Este artículo es una breve introducción a la ETC para ayudar a las enfermeras a darse cuenta de la importancia que tiene este área de estudio y trabajo. Proporcionar cuidados culturalmente adecuados, seguros y significativos se ha convertido en una necesidad para las enfermeras del presente y del mañana. Las enfermeras están retadas a utilizar los conceptos, los principios, las técnicas y los resultados de las investigaciones, para así tener una guía en sus tomas de decisión, y así poder proporcionar un cuidado culturalmente adecuado a personas de diferentes culturas. El resto es, pues que todas las enfermeras estén entrenadas en ETC para facilitar el trabajo de cuidar a muchas personas en un mundo que se mueve rápidamente y se va haciendo multicultural.

\section{BIBLIOGRAFÍA}

LEININGER, M. (1970). Nursing andAnthropology:

Two Worlds to Blend. New York, NY: John Wiley and Sons.

-(1978). Transcultural Nursing: Concepts, Theories, and Practices. New York, NY: John Wiley and Sons.

-(1991). Culture Care Diversity and Universality:

A Theory of Nursing. New York, NY: John Wiley and Sons.

-(1995). TransculturalNursing: Concepts,

Theories, Practices. Columbus, OH: McGrawHill.

-(1988). Care: The Essence of Nursing and Health Care. Detroit, MI: Wayne State University Press.

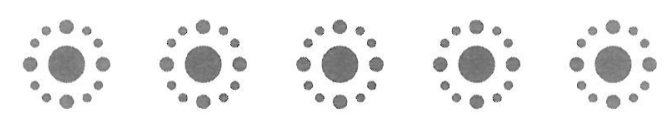




\section{CARING FOR THE CULTURALLY DIFFERENT NECESSITATES TRANSCULTURAL NURSING KNOWLEDGE AND COMPETENCES}

A $\mathrm{s}$ our world becomes more diverse and complex one realizes the need to know and understand people who speak and act differently. Nurses are in a unique role to understand clients and their families of different cultures as they care for or about them. Nurses need, however, to be prepared in order to become competent to care for people of different beliefs and lifeways. This is a worldwide imperative for nurses as they function knowingly and effectively in the $21^{\text {th }}$ Century.

In anticipation of this critical need, the field of study and practice of transcultural nursing (TCN) began with my leadership in the early 1950 s and has grown worldwide as an imperative for professional nurses (Leininger, 1970, 1978, 1995). The idea of transcultural nursing as a special area of study was new to many nurses and so it was slow to take hold and be understood by them until the late 1980s. The lack of educational programs and mentorship was evident until recent decades. Today transcultural nursing is well established so nurses can learn and use TCN concepts, principles, and researchbased knowledge in providing culturally congruent care to immigrants, refugees, and clients of diverse cultures or subcultures. Transcultural nursing is viewed today as one of the most significant breakthroughs in nursing and will be even more important and imperative for all nurses in this $219 t$ Century. Because of its holistic focus of human beings it makes a difference in the quality of health care, in recovery, in well being outcomes, or in the dying process of clients (Leininger, 1978, 1995).

\section{-What is Transcultural Nursing?}

At the outset, it is important to understand the meaning and focus of transcultural nursing. As the founder of this discipline field, I have defined transcultural nursing as a formal area of study and practice that is focused on culturally-based care. health and illness beliefs! values. and practices of people in order to help them maintain or regain their health or to face disabilities. or death (Leininger, 1978, 1995). The concepts of culture and care were closely interwoven to establish the philosophy, nature, and essence of transcultural nursing as a new body of knowledge and practice for nursing. The concept of culture came from anthropology and care came from nursing to be blended together in one major focus. Essentially culture refers to the beliefs. values. symbols. and lifewavs of particular cultures that are learned. practiced. and generally passed on with different generations as guides to living; whereas the concept of care comes from nursing. I defined care as the essence and distinct feature of nursing to enable people to maintain or remain their health or well being or to deal with illness. disabilities. or death (Leininger, 1970, 1981, 1988, 1991). As culture and care were synthesized together, the new field of transcultural nursing came into existence.

Research-based knowledge was developed along with creative practices which has provided a different way to know, understand, and care for clients of different or similar cultures. Transcultural nursing became meaningful as nurses focused simultaneously on culture and care in peoples' lifeways, in healing, or in helping people face death or disabilities. Providing culturally congruent and safe care has made a difference in whether people get well, remain ill, or have unfavorable outcomes. Hence, transcultural nursing has become a unique and different area of study and practice during the past four decades. Human beings' care beliefs, values, and desired lifeways are incorporated into nursing and health services.

-Why is Transcultural Nursing so Important Today?

Transcultural nursing is very important today due to the great mobility of peopb worldwide and to modern technological modes of communication and transportation. Human beings are moving about and communicating with people with very rapid lifestyles or lifeways. Accordingly, nurses are expected to care for strangers from many different

* Dr. Leininger is Professor Emeritus at Wayne State University (Detroit, Michigan) and Adjunct Professor at the University of Nebraska Medical Center, College of Nursing. She is the founder of the field of Transcultural Nursing and a leader in theory and research. 
cultures today and even more than in the past. Other specific reasons and some guiding principles can be offaed next. First, all human beings are bor4 live, die, and expect to be cared for within a cultural perspective. Second, culturally-based care becomes very meaningful to clients when they are ill or well and is powerful in healing outcomes. Third, nurses need to incorporate cultural care values, beliefs, and lifeways into their practices that fit with or are congruent with the lifeways and interests of clients for therapeutic benefits to them. Fourth, professional care with a cultural care focus demonstrates healing power to clients and reinforces my belief that there can be no curing without caring. Fifth, recovery from illnesses or handicaps or to face death necessitates that nurses understand the clients total lifeways and caring patterns to be helpful to people. Sixth, although integrated care and cultural factors are often invisible, or limitedly valued by the public, they are o en the most critical factors to help people. Seventh, what most people want from nurses when they come to hospitals, clinics, and other health care agencies is good nursing care that reflects knowledge and sensitivity to those being helped. Nurses as the most direct caregivers have a special opportunity to practice transcultural nursing. Eighth, when cultural care values are understood and practiced by nurses this can prevent clients from being uncooperative and clients feeling they are misunderstood or avoided. Thus, transcultural nursing is imperative for nurses today to attain the goal of promoting culturally congruent care. Transcultural nursing makes nursing meaningful and provides many rewards in caring for the culturally different.

The goal of transcultural nursing is therefore to provide culturally congruent care to people of diverse or similar cultures (Leininger, 1978, 1995). The concept of culturally congruent care within the theory of «Culture Care Diversity and Universality» is an important means to attain this goal and to discover new knowledge for nursing practices. The theory helps to guide nurses to discover new knowledge and to make assessments, decisions, and actions that are beneficial and meaningful to clients (Leininger, 1991). Most importantly, the theory helps nurses to discover culture specific care for clients of diverse cultures such as Spanish,
African, Anglo-American, Greek, Italian, Portuguese, and many other cultures which nurses may encounter in any typical day or night. And providing culturally congruent care necessitate the use of research knowledge along with creative strategies that fit with the lifeways of clients of different cultures. With transcultural nursing practices, nurses will find cooperative clients and clients who feel respected and who feel their cultural heritage and lifeways are understood.

More and more consumers expect nurses will understand and respect their cultural values and beliefs and will help them in meaningful and appropriate ways. Hence, the purpose of transcultural nursing is to continue to discover new and beneficial ways to help clients of diverse cultures and the goal of transcultural nursing is to provide culturally congruent care (Leininger, 1991, 1995). When such purposes and goals are maintained, then clients will not experience negative outcomes such as cultural imposition and other unfavorable outcomes which will be briefly discussed next with examples.

-Ethnocentrism and Cultural Imposition: Major Concepts of Concern to Nurses.

Ethnocentrism and cultural imposition are extremely important concepts for nurses to understand. Ethnocentrism refers to the belief that one's own values. beliefs. and ways of knowing and doing are the best. or superior to others (Leininger, 1978,1995). While one values their own beliefs and lifeways, problems arise when these beliefs become too strong and control others who are culturally different in nondesirable ways.

Cultural imposition refers to the tendency to impose one's ethnocentric beliefs. values. and practices onto another person or group limiting freedom and respect of a human being (Leininger, 1995). Cultural imposition is closely related to ethnocentrism because ethnocentrism often leads to cultural imposition. Both concepts often lead to cultural clashes, cultural pain, and cultural conflicts between nurses and clients. A few cultural examples help to recognize the relevance and importance of ethnocentrism and cultural imposition in transcultural nursing situations and to prevent them in care practices.

Situation 1. Mrs. Jose is a 35 year old Mexican American mother who came to the hospi- 
tal for a checkup for her three month old baby. The pediatric nurses were so pleased to see her «plump and smiling baby,» that they kept staring at the baby and repeatedly said to the mother, «What a beautiful child with its beautiful hair and eyes.» The Mexican American mother became very restless and moved away from the nurses. Soon the mother left the hospital as she believed the nurses were casting an evil eye on her child. The nurses were baffled about the mother's behavior, but learned from a transcultural nurse specialist that staring and praising the Mexican baby is often viewed by Mexican mothers as «casting an evil eye onto the child.» Such behavior is believed to lead to sickness and possibly death of the baby. Thus, the motha was very concerned about the nurses' behavior and took the baby home to prevent illness and harm to her baby. The transcultural nurse taught the nurses to touch the baby when they praise the baby's beauty as this would prevent harm to him. Such transcultural nursing knowledge of another's beliefs is imperative for nurses to know and apply in their care practices. In this situation, the nurses' ethnocentric professional ways of praising beautiful babies became a real threat to the Mexican mother and her baby.

Situation 2. Another common transcultural nursing care incident or problem is related to pain meanings and expressions and how best to handle pain with clients of diverse cultures. It is well known in transcultural nursing that pain varies among clients of different cultures and all clients cannot be treated alike. Mrs. Senaro is a 55 year old Catholic Philippine woman who had uterine surgery. The physician had prescribed a «high dosage of post-operative medication to relieve her of any pain.» Mrs. Senaro heard the physician tell this order to the nurse. Later Mrs. Senaro told the nurse, «Please do not give me a lot of medicine.» After the first injection of medicine, the client never asked for any more pain medication and rejected additional offers made by the nurse to carry out the physician's orders. The nurse complied with the client's request but did not understand why the client did not want something for pain that the nurse thought she badly needed. Later the cultural reasons for the Philippine client refusing pain medication were explained to the nurse by a transcultural nurse specialist working in the hospital. She told the nurse that the reasons for the Philippine client's refusal of medication were that the client feared drug addiction, accepted stoicism, and valued redemptive suffering as a Roman Catholic. For these major reasons, Mrs. Senaro did not want pain medication and declined the offers of medication made by the nurse. The nurse was tempted to practice cultural imposition but learned that culturally different pain responses among and between cultures needed to be respected.

Incident 3. Caring for Jehovah Witness clients is often very difficult for nurses and other professionals to handle as medically indicated blood transfusions are usually viewed as necessary from a professional viewpoint. However, Jehovah witness clients have different religious beliefs about blood transfusions. Abie was a 27 year old Jehovah witness woman who was admitted to the hospital for surgery. On admission she immediately told the nurse and physician that under no circumstances did she want to receive any blood transfusions before, during, or after surgery. The nurse and physician were troubled about this expectation as both wanted to fulfill their professional responsibilities and maintain their ethnocentric professional beliefs. To the physician the Hippocratic Oath was important and the nurse valued her professional code of ethics. Thus an ethical and moral conflict was evident with Abie's cultural religious beliefs about prohibited blood transfusions. The nurse and physician upheld her request but they were greatly concerned about her survival. However, Abie and her family prayed hard to come through the surgery without any blood transfusions. She did recover successfully and her family was greatly relieved that no one imposed their cultural beliefs and values on her. Abie was relieved that there was no violation of God's laws by having a blood transfusion as this would have meant spending eternity «in nothingness.» The nurse and physician practiced transcultural nursing and avoided cultural imposition practices.

This brief article is a short introduction to transcultural nursing to help nurses to realize: the great importance of this area of study and practice. Providing culturally congruent, safe, and meaningfill care has become imperative for nurses today and tomorrow. Nurses are challenged to use trans- 
cultural nursing concepts, principles, practices, and research findings to guide them in their decisions in order to provide effective and congruent care to the diverse cultures they serve. The great challenge is therefore for all nurses to become prepared in transcultural nursing to facilitate their work as they care for many clients in a rapidly growing multicultural world.

\section{REFERENCES}

Leininger, M. (1970). Nursing and Anthropology:

Two Worlds to Blend. New York NY: John

Wiley and Sons.
-(1978). Transcultural Nursing: Concepts, Theories, and Practices. New York NY: John Wiley and Sons.

-(1991). Culture Care Diversity and Universality: A Theory of Nursing. New York NY: John Wiley and Sons.

-(1995). Transcultural Nursing: Concepts, Theories, Practices. Columbus, OH: McGraw Hill.

-(1988). Care: The Essence of Nursing and Health Care. Detroit, MI: Wayne State University Press.
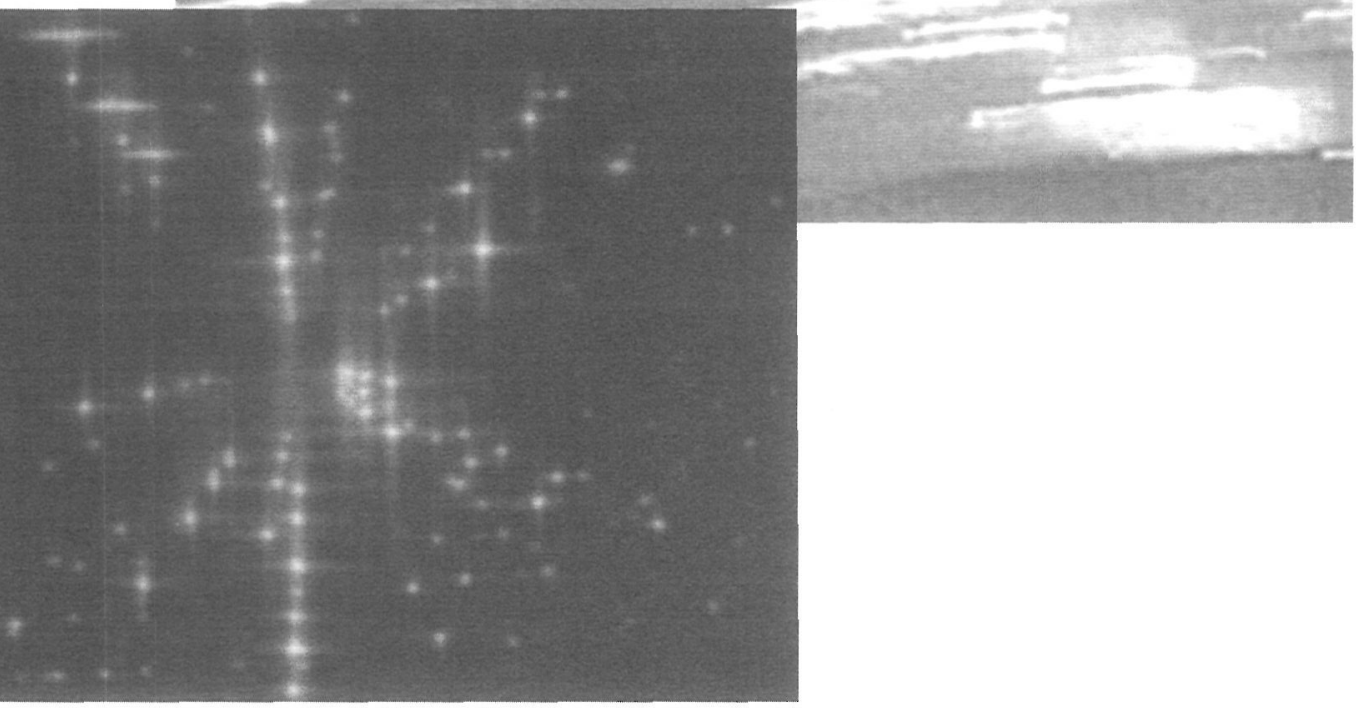